\title{
The Sexual Socialization and Parenting Styles and the Lack of Secure Attachment Provided to Adolescent Rapists by their Families
}

\author{
Esty Hellia Mainap ${ }^{1, *}$ Johanna Debora Imelda ${ }^{2}$
}

\author{
${ }^{1}$ Universitas Indonesia \\ ${ }^{2}$ Universitas Indonesia \\ ${ }^{*}$ Corresponding author. Email: estyhelliam@gmail.com
}

\begin{abstract}
The Annual Note of the National Commission on Violence Against Women states that the number of cases of violence against women was quite high in Indonesia between 2015 and 2018 (Komisi nasional Anti kekerasan terhadap perempuan [The National Commission on Violence Against Women] 2015; (Annual Record) komnas perempuan tahun 2015; Komisi nasional Anti kekerasan terhadap perempuan [The National Commission on Violence Against Women] 2016; (Annual Record) komnas perempuan tahun 2016; Komisi nasional Anti kekerasan terhadap perempuan [The National Commission on Violence Against Women] 2017; (Annual Record) komnas perempuan tahun 2016; Komisi nasional Anti kekerasan terhadap perempuan [The National Commission on Violence Against Women] 2018; (Annual Record) komnas perempuan tahun 2018). Sexual violence secured the top position among cases of aggression against women between 2014 and 2017 and rape cases registered highest in the cases of sexual violence from year to year: in 2014, a total of 1033 cases were filed; 2,448 cases were reported in 2015; 1468 cases were registered in 2016; and 1530 cases occurred in 2017 (Komisi nasional Anti kekerasan terhadap perempuan [The National Commission on Violence Against Women] 2015; (Annual Record) komnas perempuan tahun 2015; Komisi nasional Anti kekerasan terhadap perempuan [The National Commission on Violence Against Women] 2016; (Annual Record) komnas perempuan tahun 2016; Komisi nasional Anti kekerasan terhadap perempuan [The National Commission on Violence Against Women] 2017; (Annual Record) komnas perempuan tahun 2016; Komisi nasional Anti kekerasan terhadap perempuan [The National Commission on Violence Against Women] 2018; (Annual Record) komnas perempuan tahun 2018). According to the data collected by the Indonesian Child Protection Commission in 2018, instances of rape by children have been rampant since 2011 and cases of rape by children increased from 147 in 2016 to 168 in 2017 (Anak 2018). The promotion of sexuality is considered taboo in Indonesian society. Most families do not clearly socialize their children to the notion of sexuality. This study aims to determine the process of sexual socialization and the parenting styles evinced by families of adolescent rapists. It finds that the values and norms with regard to appropriate sexual behavior are ill-absorbed by such children because their families are not able to establish secure attachment with them. Insecure attachment can increase children's access to information about sexuality from socialization agents other than family with whom they feel safe. The present case study uses the qualitative research methodology and the results obtained from the investigation illustrate that the authoritarian, permissive, and uninvolved parenting styles create insecure attachment in children. The outcomes of the study lead to the conclusion that the sexual socialization obtained by adolescent rapists is incomplete and that the information they receive lacks clarity because their parenting tends to be authoritative, uninvolved, or permissive, and lacks adequate monitoring. When socialization and parenting occur without secure attachment, adolescent rapists are able to seek sexual socialization from other agents such as peers and the mass media without adequate control being established on such interactions.
\end{abstract}

Keywords: Socialization, Parenting Styles, Attachment, Family, Adolescent Rapists 


\section{INTRODUCTION}

The World Health Organization (WHO) (WHO 2017) reports that 1 in 3 women around the world experiences physical aggression and sexual violence. The National Commission on Violence Against Women notes in its Sexual Violence Guidelines Module that at least 35 women have been victims of sexual violence every day during a 12-year period (2001 - 2012) (Komisi nasional Anti kekerasan terhadap perempuan [The National Commission on Violence Against Women] 2012). In 2013, cases of sexual violence increased to 5,629 in comparison to 4,336 in 2012. Most of the cases involved rape or sexual harassment (Komisi nasional Anti kekerasan terhadap perempuan [The National Commission on Violence Against Women] 2012). The National Commission on Violence Against Women state in its annual report that the number of violence against women was quite high in Indonesia between 2015 and 2018 (Komisi nasional Anti kekerasan terhadap perempuan [The National Commission on Violence Against Women] 2015; (Annual Record) komnas perempuan tahun 2015; Komisi nasional Anti kekerasan terhadap perempuan [The National Commission on Violence Against Women] 2016; (Annual Record) komnas perempuan tahun 2016; Komisi nasional Anti kekerasan terhadap perempuan [The National Commission on Violence Against Women] 2017; (Annual Record) komnas perempuan tahun 2016; Komisi nasional Anti kekerasan terhadap perempuan [The National Commission on Violence Against Women] 2018; (Annual Record) komnas perempuan tahun 2018). Sexual violence secured the top position among cases of aggression against women between 2014 and 2017 and rape cases registered highest in the cases of sexual violence from year to year: in 2014, a total of 1033 cases were filed; 2,448 cases were reported in 2015; 1468 cases were registered in 2016; and 1530 cases occurred in 2017 (Komisi nasional Anti kekerasan terhadap perempuan [The National Commission on Violence Against Women] 2015; (Annual Record) komnas perempuan tahun 2015; Komisi nasional Anti kekerasan terhadap perempuan [The National Commission on Violence Against Women] 2016; (Annual Record) komnas perempuan tahun 2016; Komisi nasional Anti kekerasan terhadap perempuan [The National Commission on Violence Against Women] 2017; (Annual Record) komnas perempuan tahun 2016; Komisi nasional Anti kekerasan terhadap perempuan [The National Commission on Violence Against Women] 2018; (Annual Record) komnas perempuan tahun 2018). This number is exclusive of other cases of sexual violence such as sexual abuse, sexual harassment, and sexual exploitation (Komisi nasional Anti kekerasan terhadap perempuan [The National Commission on Violence Against Women] 2015; (Annual Record) komnas perempuan tahun 2015; Komisi nasional Anti kekerasan terhadap perempuan
[The National Commission on Violence Against Women] 2016; (Annual Record) komnas perempuan tahun 2016; Komisi nasional Anti kekerasan terhadap perempuan [The National Commission on Violence Against Women] 2017; (Annual Record) komnas perempuan tahun 2016; Komisi nasional Anti kekerasan terhadap perempuan [The National Commission on Violence Against Women] 2018; (Annual Record) komnas perempuan tahun 2018). The statistics for rape perpetrated by lovers or family members in the domestic arena are also elevated (Komisi nasional Anti kekerasan terhadap perempuan [The National Commission on Violence Against Women] 2015; (Annual Record) komnas perempuan tahun 2015; Komisi nasional Anti kekerasan terhadap perempuan [The National Commission on Violence Against Women] 2016; (Annual Record) komnas perempuan tahun 2016; Komisi nasional Anti kekerasan terhadap perempuan [The National Commission on Violence Against Women] 2017; (Annual Record) komnas perempuan tahun 2016; Komisi nasional Anti kekerasan terhadap perempuan [The National Commission on Violence Against Women] 2018; (Annual Record) komnas perempuan tahun 2018).

Rape can happen to anyone, regardless of age or gender. Unfortunately, children are no longer merely subjected to victimization by adult sexual violence; instead, children can also commit acts of sexual violence. The Indonesian Child Protection Commission states in an article on the ECPAT Indonesia page that 1,965 cases of sexual violence against children were registered between 2011 and 2016 (Ardian 2017). This excessive scale was followed by high rates of rape committed by children (Ardian 2017). This statement is supported by data collated by the Indonesian Child Protection Commission in 2018 on children who were reported to commit rape between 2011 and 2017 (Anak 2018). according to these data, instances of rape perpetrated by children have been on the rise since 2011 and according to the statistics, this increase is exemplified by the 168 cases reported in 2017 vis-à-vis 147 cases in 2016 (Anak 2018). Most children who rape belong to the age range of 15-19 years (Kruttschnitt 1989). So far, sexual socialization is considered a taboo by Indonesian society and most families choose not to provide sex education.

The present study scrutinizes the socialization of sexuality through four methods: affective, cognitive, operant, and observational. It examines parenting styles through the four types of authoritative, authoritarian, permissive, and uninvolved. The tasks of socialization and parenting are both undertaken by a child's family. The lack of secure attachment results in the failure of the process of sexual socialization through the act of parenting. Such a deficiency also opens an adolescent's access to information from other socialization agents and the child's interactions with these external agents is likely not to be controlled. This study aims to determine 
the associations between a child's sexual socialization and parenting styles as determined by an examination of the families of adolescent rapists and the attachments attained by the child perpetrators of sexual crimes. The socialization values and norms passed on by authoritarian, uninvolved, or permissive parenting styles that did not appropriately control the child's external interactions were not sufficient for children to imbibe adequate knowledge about their sexuality. The socialization and parenting styles mentioned above are generally found to create insecure attachments in children. Insecure attachment can increase an adolescent's access to external information about sexuality obtained from socialization agents other than family members with whom they feel secure to explore the subject. Figure 1 provides the theoretical framework for study.

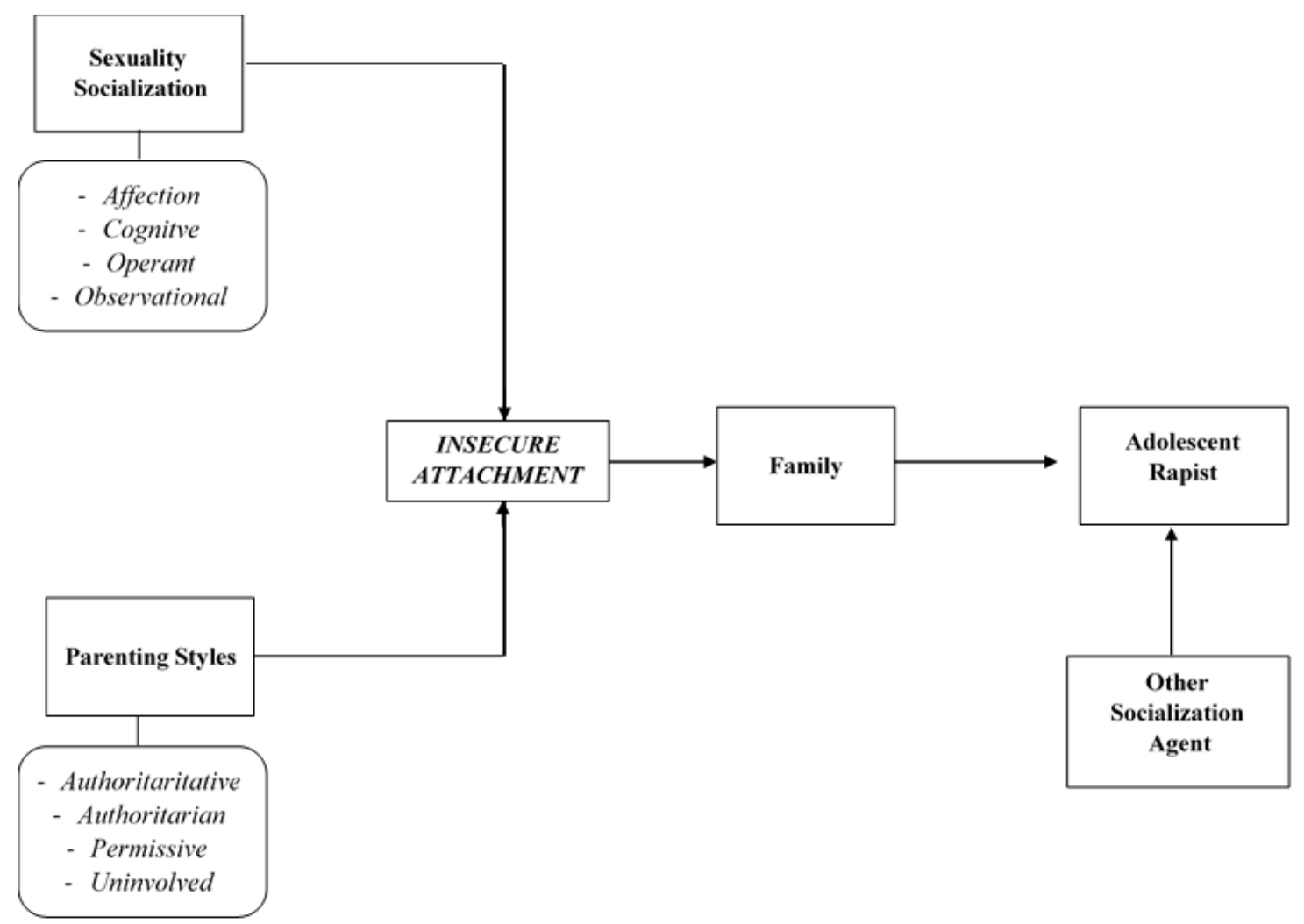

Figure 1 Theoretical Framework.

\section{METHOD}

The present study utilized the qualitative case study methodology and used the purposive sampling technique to determine informants who evidenced relevant relationships with the problem under investigation (Bryman 2012). Data were collected by conducting a literature review, documentation studies, in-depth interviews, and through the observation of the circumstances of the respondents. Qualitative analysis techniques were employed on the collected data: first, verbatim transcripts of the interviews were prepared; next, relevant data were coded verbatim from the transcripts; subsequently, a selective coding was performed to obtain the principal ideas and to collate the findings of the investigation; finally, the collated data were analyzed to arrive at conclusions (Bryman 2012).

To obtain data, the researchers acquired access to informants housed at the Handayani Jakarta Social Rehabilitation Center for Children Who Need Special
Protection. The informants of this study comprised adolescent rapists (3) and their families, as represented by parents and siblings (4).

\section{RESULTS AND DISCUSSION}

\subsection{General Description of the Informants}

The informants interviewed for the present investigation were children who were still attending school when they raped their victims. They belonged to the age range of 15 to 17 years. They were born to respectable families without any criminal records. In economic terms, some of the children's families were affluent, while others were not. The children were also active in school organizations; and had earned achievements in their schools.

These adolescents had committed either seductive or angry rape. Seductive rape occurs through an intimate situation created consensually by both parties and the 
circumstances are misinterpreted by the rapist as an agreement for sexual intercourse. Angry rape is perpetrated in rage or jealousy. In one instance, the perpetrator was infuriated by his lover exchanging romantic messages with another man, and the rape resulted from the belief that the lover was promiscuous.

The adolescents raped because they were affected by exposure to pornographic photographs and videos available on social media. Often, the rape was found to occur because an opportunity presented itself; or due to anger when the rapist's lover was caught sexting with another person; or because of intimate situations that were initially consensually created but that led to rape.

\subsection{The Role of the Family in Ensuring Sexual Socialization}

A child can be socialized to sexuality in a variety of ways (Bern 2007; Child, Family, \& School). The methods of socialization differ according to specific cultures, family circumstances, individual personalities, and the prevailing situation (Bern 2007; Child, Family, \& School). Socialization is a process through which individuals learn the norms, values, behavior, encouragement, and knowledge that supports their becoming members of a group and to fulfill appropriate roles in society (Clinard, \& Meier 2016). The present study found that the adolescent rapists did obtain a degree of sexual socialization from their families; however, their sexual education is not sufficient. In terms of the classifications of socialization, the adolescent rapists who were interviewed did not receive attachment from their parents. They also did not feel attachment to their parents because their interactions with their parents were rare. Their parents never asked them about the problems they faced and never attempted to discover what was troubling them. The adolescents claimed their lack of intimacy and interaction with at least one of their parents. In one case, attachment existed between the concerned adolescent and an older sibling, but this attachment was not accompanied by intense socialization because this sibling already had her own family and children so she could not focus on paying due attention to the adolescent and to his socialization through affective ties.

Turning to cognitive means of socialization, the adolescents were warned by their families to be careful in their interactions, especially with women. The families of the adolescent rapists did provide sexual socialization using instruction strategies and explanations. The adolescents were allowed to date when romantic affection occurred naturally and was considered a learning experience. The adolescents were also warned not to cross the line and to avoid getting their girlfriends pregnant. However, the parents never taught them to respect women. The boys were not informed of the hormonal changes they could expect and be alert against when they reached reach puberty. They were not warned about the effects of premature sexual intercourse on adolescents. Thus, the boys never appreciated the restrictions imposed on them by their parents. Thus, the parents did provide information about sexuality through the two cognitive strategies or instruction and explanation, but their inputs were not imparted in a manner that was detailed and that could be accurately absorbed by adolescents. Communication is a process through which meaning is obtained by the receiver (Bungin 2011). If the adolescents were not able to apprehend the significance of the message in full, or if the purpose of the communication was not clear to them, the socialization process may be deemed to have failed.

With regard to the operand method, the family provided socialization through the strategy of providing feedback or responses to actions taken by adolescents and by penalizing unwanted adolescent behaviors. Adolescents were scolded for their intimate and inappropriate conduct with their romantic partners in the presence of their families. In addition, the adolescents were also reprimanded when they were caught bringing a girlfriend home when no one else was present. However, the prohibitions and responses were not accompanied by adequate explanations and clear reasoning. The parents would only express their worries about what their neighbors were saying. Thus, the adolescents' knowledge about sexuality remained incomplete.

In terms of the observation method, the families of the rapists were not found to contribute to their sexual socialization. Instead, other outreach agents took on a more significant role for this method. Mass media and friends were found to be the most significant parties responsible for the provision of negative sexual socialization for the interviewed adolescents. Even though the family's participation is very important, the modeling can be accomplished without a direct family example. Instead, observational socialization may be accomplished by boys through the noting of the responses and conduct of others on whom they model their own sexual behavior (Bern 2007; Child, Family, \& School). In the present study, the role of the family was found to be limited to sexual socialization through cognitive and operant methods.

\subsection{Family Uninvolvement in Proper Parenting}

The family is the first post-natal environment for a child. It presents a child's initial outreach through the act of parenting (Pasaribu, Hastuti, \& Alfiasari 2013), which protects and prepares the child for life in the outside world (Ebrahimi et al. 2017). The styles of parenting provided by families can be observed from the ways in which a family communicates the values and norms to accomplish a child's socialization. Four parenting styles are generally acknowledged: authoritative, authoritarian, 
permissive, and uninvolved (Bern 2007; Child, Family, $\&$ School). These styles were sought to be ascertained by the researchers vis-à-vis the families of the adolescent rapists. The conducted interviews revealed that the families of adolescent rapists evinced very diverse parenting styles and that every family exhibited more than one parenting style. The style of parenting depended on the methods and the contexts of the particular type of socialization sought to be obtained. The findings indicate the existence of a variety of parenting styles to accomplish socialization through cognitive methods. However, one parent in each family was found to be uninvolved in the provision of information to the interviewed adolescents about the values and norms that should be applied to sexuality and sexual behavior. In fact, a complete lack of interaction was noted between the uninvolved parents and the adolescents.

In families that exhibited the authoritative parenting style, it was discovered that an older sibling tended to better understand the adolescent's needs. In one case, the sibling was described as being able to explain the dating prohibition in words and tones that were easy for the adolescent to understand and were comfortable for him to hear. However, the authoritative parenting style did not result in the full sexual socialization of the young boy because as noted above, the sibling's focus had shifted to her own family and children. In the authoritarian style, the adolescents were never asked for a response to the prohibitions and warnings issued by their parents. The parents were always suspicious and tended not to believe the child's assertions. Parents also never tendered a clear explanation of their prohibitions or explained the potential effects of deviant sexual behavior by the adolescents. Therefore, the adolescents did not achieve a clear understanding of sexuality because their socialization was inadequate and one-sided. To be complete, all communication must be bidirectional and dyadic.

In this study, the permissive style of parenting was found to imply that parents forbade the adolescents from excessive dating but accorded the adolescents the opportunity to interpret their words. Parents also acceded to their adolescents' desires in the hope that the adolescents understood their expectations and would be obedient and well behaved, without providing the juvenile children with due explanations. Parents also assumed that their adolescents were already sexually informed and did not need further detailed explanations In reality, however, the adolescents claimed that they did not understand the appropriate social expectations from them with regard to sexuality and religion and that they required instruction and information.

Uninvolved parents were found to rarely interact with the adolescents, especially in terms of sexual socialization. Such parents never approached the adolescents or asked how they were doing at school. The interviewed adolescents admitted they almost never talked to one of their parents unless they needed help. In addition, the family did not supervise or control any of the activities of the adolescents, whether they were in their rooms or on their electronic devices, or in their interactions with their friends outside the home.

The table below illustrates the trends found in the parenting styles adopted by the families of the adolescent rapists vis-à-vis the sexual socialization provided by them through the four methods mentioned above. The results obtained from this study revealed that the families rarely evinced a single category of parenting; instead, they tended to combine all four styles. In Table 1, ' $\mathrm{X}$ ' indicates the absence of the parenting style while ' $\mathrm{V}$ ' suggests the presence of the particular parenting style. Cells with ' $\mathrm{VV}$ ' illustrate the predominence of the parenting style despite the existence of varied styles as found in the study.

Table 1. Socialization and Parenting Styles that Appear in the Families of the Adolescent Rapists

\begin{tabular}{|l|c|c|c|c|}
\hline \multirow{2}{*}{$\begin{array}{l}\text { Socializati } \\
\text { on }\end{array}$} & \multicolumn{4}{l}{ Parenting Styles } \\
\cline { 2 - 5 } & $\begin{array}{l}\text { Authorit } \\
\text { ative }\end{array}$ & $\begin{array}{l}\text { Authorit } \\
\text { arian }\end{array}$ & $\begin{array}{l}\text { Permiss } \\
\text { ive }\end{array}$ & $\begin{array}{l}\text { Uninvol } \\
\text { ved }\end{array}$ \\
\hline Affection & $\mathrm{V}$ & $\mathrm{X}$ & $\mathrm{V}$ & $\mathrm{V} \mathrm{V}$ \\
\hline Operant & $\mathrm{V}$ & $\mathrm{V}$ & $\mathrm{V}$ & $\mathrm{V}$ \\
\hline Cognitive & $\mathrm{V}$ & $\mathrm{VV}$ & $\mathrm{V} \mathrm{V}$ & $\mathrm{V}$ \\
\hline $\begin{array}{l}\text { Observati } \\
\text { onal }\end{array}$ & $\mathrm{X}$ & $\mathrm{X}$ & $\mathrm{X}$ & $\mathrm{V} \mathrm{V}$ \\
\hline
\end{tabular}

The variation in parenting styles illustrated in Table 1 demonstrates that no particular parenting styles can guarantee the success of a socialization process. However, it is true that parenting can influence the process of providing family outreach. The results obtained in this study elucidate the role of the family as an agent of socialization and denote the importance of parenting styles for adolescents. The styles of parenting were found to be quite diverse: the authoritarian style of socialization utilizes operand and cognitive methods; permissive styles employ cognitive, operant, and affective socialization techniques; and the uninvolved style of parenting are used to set examples and provide affection.

The statement that parenting is a determinant of the success of the socialization process is true. In fact, many of the parents of the interviewed adolescent rapists evinced the uninvolved style and did not provide adequate socialization through parenting efforts. Thus, the young boys were not provided with sufficient secure attachment or example, and their socialization process failed. Instead of modeling their behavior on their parents and families, the adolescents were tempted to 
observe and imbibe sexual information from the wrong sources, namely through their peers and via mass media. The interaction of these adolescents with their peers was not controlled, and the information they obtained about sexuality was not appropriate or complete. Adolescents are in an active period of reproductive development and they require adequate explanation of sexuality. Parental inputs and restrictions on sexuality can be limiting for adolescents but can also provide detailed clarifications and influence adolescent behavior in a positive manner. Adolescents who receive appropriate sexual socialization from their parents and families are able to apprehend their limits Conversely, information obtained from mass media may exert the most dangerous socialization influence on adolescents with regard to sexuality (Bern 2007; Child, Family, \& School) because the parties who deliver such socialization over mass media are not close to the adolescents. Adolescents may receive negative sexual socialization from mass media without such adverse information being followed by an explanation of beneficial and healthy conduct. Hence, children take in only the negative aspects of sexuality without learning about fitting and desirable conduct (Bern 2007; Child, Family, \& School). By limiting their inputs to two methods of socialization,cognitive and operand, the other two methods of affection and observation seem to be neglected.

\subsection{Insecure attachment and sexual socialization}

Attachment is a bond that binds people in one space and endures over time (Bern 2007; Child, Family, \& School). It is defined as a strong emotional bond between two people. A study by Santrock found that comfortable contact and not breastfeeding babies was the most important element in the growth of attachment between children and their caregivers (Santrock 2002).

Data from the interviews evince interesting features about the families of adolescent rapists: they lack attachment to each other, especially with respect to the provision of sexual. Parenting styles affect the formation of attachment between parents and adolescents (Bern 2007; Child, Family, \& School), but the parenting styles provided by the families of the adolescent rapists were unable to create a secure attachment, which could have been used. as a method of appropriate socialization. The findings of previous studies asserting that attachment is the key to the socialization process (Bern 2007; Child, Family, \& School) were observed to be true in the course of the present study. The families of the adolescent rapists attempted to provide socialization in various ways but neglected to utilize the method of affection through attachment. This deficiency triggered the failure of the socialization process for the adolescent rapists.
Insecure attachment was demonstrated also in the case of an adolescent victim who did not feel comfortable telling her mother about the problem she was experiencing because she was afraid of adding to her mother's anxieties and problems. When deviant sexual behavior by adolescent rapists becomes an increasing problem, the victims still feel afraid to tell their parents for fear of being scolded. Children who attain a secure attachment with their parents and families will not hesitate in expressing their feelings, both positive or negative, for fear of adverse effects (Davies 2011). The attachment obtained by juvenile rapists was found to be insecure as can be seen from the paucity of their interactions with their family members as well as their resistance and neglect of the presence of their parents.

Close associations between parents and adolescents can help to create a sense of protection in adolescents, minimizing the influence of negative inputs (Davies 2011). Family bonding can also create comfort and happiness during interactions (Ebrahimi et al. 2017). If attachment informs the process of sexual socialization between families and adolescents, the topic of sexuality becomes easier, more positive, and even enjoyable for adolescents. In addition, Davies explains that attachment can also provide a sense of security for adolescents, which enables adolescents to believe that they can explore the outside world with the parties with whom they form close ties (Davies 2011).

The process of socialization and parenting for the families of adolescent rapists does not indicate a secure attachment between the parties that provide socialization (family) with those who are socialized (adolescent rapists). Even when socialization is provided through other methods, children continue to behave in a deviant manner because they seek attachment with outsiders who can provide them with secure attachment. This study found that the adolescent rapists established such secure attachments with their lovers, peers, and mass media. Unfortunately, the information about sexuality obtained by these adolescents from their peers, lovers, and the mass media (other socialization agents) was not controlled by their parents and other family members.

The rarity of interaction between adolescents and families, especially in terms of their sexual socialization, also contributed to the lack of secure attachment between the adolescent rapists and their families. The other agents of socialization made them feel more comfortable and they felt at liberty to to explore the outside world with these external agents. Unfortunately, their interactions with these agents of socialization were not controlled.

This study found that peers, lovers, and the mass media contributed to the socialization process through the method of observation. Mass media induced the adolescent rapists to imitate photographic and 
audiovisual content on social media that contained elements of intimacy and pornography. The adolescent rapists were also often influenced to commit sexual violence in response to a lover's reactions to the intimate interactions of other adolescents and couples. In addition, adolescents also emulate peers who are observed to be dating in quiet spaces or are witness to sex chats between lovers and friends. Adolescents do not feel that their actions are wrong because they see other people performing the same acts. They also never receive preventive advice, embargos, or detailed clarifications that proscribe sexual intercourse with their girlfriends and apprise them of the serious consequences that can result from such actions.

Further, adolescents learn from mass media, which is dangerous, because this education emanates from parties who are not bonded with affection. If the appropriate positive inputs are not provided through affective means, young people are likely to imitate the negative information disseminated by the media (Bern 2007; Child, Family, \& School). In sum, the peers and lovers of adolescents, and the mass media that provide them with information about sexuality are all agents whose interactions cannot be monitored.

Incomplete and unclear information on sexuality is not enough to secure appropriate behavior by an adolescent. However, the communication offered by parents in the process of sexual socialization through parenting is often one-way, incomplete, and does not ensure the understanding and acquiescence of the adolescents themselves. Since the message is not communicated properly, (Bungin 2011) the socialization process fails.

On the contrary, secure affiliations with external agents such as peers, mass media, and lovers caused the interviewed rapist adolescents to gain access to improper sexual socialization from incompetent sources.

\section{CONCLUSION}

This study concludes that (1) Family involvement that only provides sexual socialization through cognitive and operant means does not provide parenting inputs that are sufficient for the security and ease of adolescents. Parenting styles tend to prefer one-way communication, be permissive, offer inadequate monitoring, and neglect methods of socialization such as affection and observation. Thus, parenting methods may be said to be incomplete. Further, parents did not expressly teach their children to respect women, to inform them of what to expect when they enter the stage of puberty, or to elucidate the adverse impacts of premature sexual intercourse on adolescents. Thus, the adolescent rapists did not comprehend the restrictions imposed on them by their parents. They were unable to accurately absorb the sex-related information provided to them by their family members. Moreover, the family unit did not seem to indulge in a two-way communication process and hence, parents remained unaware of the extent of their children's understanding or to ascertain the doubts that remained in the minds of the adolescents. The mass media, peers, and girlfriends of the adolescent rapists were most attributable to their negative sexual socialization, through the interchange of potentially inaccurate information about sexuality. Of all the external socialization agents, mass media were found exert the most dangerous impact, because the adolescent rapists learned from a distance. The negative inputs from the mass media were not countered by accurate information and the adolescents were thus liable to imitate the unhealthy exemplars.

(2) The most prevalent parenting style received by the adolescent rapists was authoritarian. It offered minimal explanations through one-way communication and did not solicit responses from the adolescents. Socialization is a process of social interaction and is synonymous with communication. Communication with outreach agents is crucial. No effective communication is possible if the information parents want to convey is not well received by adolescents. In a few cases, the attitudes of parents who let adolescents think for themselves about what they should and should not do influenced adolescents to seek information from other socialization agents who may or may not have delivered inappropriate sexual knowledge to them.

(3) The sexual socialization and style of parenting provided to the adolescent rapists created an insecure attachment between them and their families, as may be evidenced by their discomfort in sharing their troubles with their parents or family members. The insecure attachment can also be seen from the lack of their interactions with their families. In addition, the expression of opposing attitudes by the adolescent rapists and their repudiation of the existence of their parents also indicate attachment insecurity, which allowed access to inappropriate sexual socialization from other incompetent socialization agents such as lovers, peers, and mass media (through social media).

In the final analysis, the commission of seductive or angry rape by adolescents may indicate the absence of secure attachment to family members, who represent the agents closest to the child and who can provide the children with competent, realistic, and complete knowledge of their emergent sexuality and sexual identities as members of a larger society. In the absence of such weighed, affective, and positive inputs, adolescents are enticed to obtain sexual socialization from external and incompetent sources that may be inaccurate and harmful to their sexual identities. 


\section{REFERENCES}

[1] WORLD HEALTH ORGANIZATION (2017), Violence Against Women, https://www.who.int/news-room/factsheets/detail/violence-against-women.

[2] Komisi nasional Anti kekerasan terhadap perempuan [The National Commission on Violence Against Women] (2012), Modul pedoman kekerasan seksual oleh komnas perempuan, https://www.komnasperempuan.go.id/file/pdf_file/ Modul\%20dan\%20Pedoman/Kekerasan\%20Seksua 1/15\%20BTK\%20KEKERASAN\%20SEKSUAL.pd f.

[3] Komisi nasional Anti kekerasan terhadap perempuan [The National Commission on Violence Against Women] (2015), Catatan tahunan (Annual Record) komnas perempuan tahun 2015, https://drive.google.com/file/d/0BwSyakH_J8_nM E9pang1UFYxbjQ/view.

[4] Komisi nasional Anti kekerasan terhadap perempuan [The National Commission on Violence Against Women] (2016), Catatan tahunan (Annual Record) komnas perempuan tahun 2016, https://drive.google.com/file/d/0BwSyakH_J8_nV GxwdzYxWDd2cHM/view.

[5] Komisi nasional Anti kekerasan terhadap perempuan [The National Commission on Violence Against Women] (2017), Catatan tahunan (Annual Record) komnas perempuan tahun 2016, https://drive.google.com/file/d/0BwSyakH_J8_nRk RNTVBxX0Q1aWs/view.

[6] Komisi nasional Anti kekerasan terhadap perempuan [The National Commission on Violence Against Women] (2018), Catatan tahunan (Annual Record) komnas perempuan tahun 2018, https://www.komnasperempuan.go.id/file/pdf_file/2 018/SIARAN\%20PERS\%202018/Lembar\%20Fakt a\%20Catahu\%207\%20Maret\%202018.pdf.

[7] Ardian, A 4 December 2017, Kajian kemensos dan ecpat indonesia tentang pelaku kejahatan seksual anak oleh pelaku anak, http://ecpatindonesia.org/berita/kajian-kemensosdan-ecpat-indonesia-tentang-pelaku-kejahatanseksual-anak-oleh-pelaku-anak/.

[8] Anak, KP, Indonesia (child protection cases by Indonesian Child Protection Commission) (3
September, 2018), Data Kasus Perlindungan Anak oleh KPAI tahun 2011-2018.

[9] Kruttschnitt, C (1989), A sociological, offenderbased, study of rape, Sociological Quarterly, vol. 30, no. 2, 305-329. DOI https://doi.org/10.1111/j.15338525.1989.tb01524.x.

[10] Bryman, A 2012, Social research methods, Oxford University Press, Oxford.

[11] Bern, RM (2007). Child, Family, \& School, Community: socialization and support, 7th edn, Thomson, Belmont Wadsworth.

[12] Clinard, MB, \& Meier, RF 2016, Sociology of deviant behavior, Cengage Learning, Boston.

[13] Bungin, B (2011), Sosiologi Komunikasi:teori, paradigma, dan diskursus tekonologi komunikasi di masyarakat.Jakarta: kencana.

[14] Pasaribu, RM, Hastuti, D, \& Alfiasari (2013), Pola pengasuhan Permisif dan Rendahnya Sosialisasi Keluarga Berisiko Terhadap Penurunan Karakter Remaja, Jurnal Ilmu Keluarga dan Konsumen, vol. 6, no. 3, pp. 163-171.

[15] Ebrahimi, L, Amiri, M, Mohamadlou, M, \& Rezapur, R (2017), Attachment styles, parenting styles, and depression, International Journal of Mental Health and Addiction, vol. 15, no. 5, pp. 1064-1068. DOI: https://doi.org/10.1007/s11469017-9770-y.

[16] Santrock, JW (2002), Life-span development:perkembangan masa hidup edisi kelima, Jilid, I, (Achmad Chusairi \& Juda Damanik, Penerjemah), Erlangga, Jakarta.

[17] Davies, D (2011), Child Development:A Practitioner's Guide, 3rd edn, The Guilford Press, New York.

[18] Rehabilitasi, Balai, Sosial Anak yang Memerlukan Perlindungan Khusus Handayani Jakarta. (Desember, 2018) [The Handayani Jakarta Children's Social Rehabilitation Center who need special protection. (Desember, 2018)], Data of Beneficiaries Balai Rehabilitasi Sosial Anak yang Memerlukan Perlindungan Khusus Handayani Jakarta 2018 